\title{
Isolation of Bioactive Compounds from Sunflower Leaves (Helianthus annuus L.) Extracted with Supercritical Carbon Dioxide
}

\author{
Zouhir El Marsni, ${ }^{\dagger}$ Ascension Torres, ${ }^{\ddagger}$ Rosa M. Varela, ${ }^{\ddagger}$ José M. G. Molinillo, $^{\ddagger}$ Lourdes Casas, ${ }^{\dagger}$ \\ Casimiro Mantell, ${ }^{\dagger}$ Enrique J. Martinez de la Ossa, ${ }^{\dagger}$ and Francisco A. Macias ${ }^{*}$,
}

${ }^{\dagger}$ Department of Chemical Engineering and Food Technology and ${ }^{\ddagger}$ Allelopathy Group, Department of Organic Chemistry, Institute of Biomolecules (INBIO), Campus de Excelencia Internacional (ceiA3), Faculty of Science, University of Cadiz, C/República Saharaui 7, 11510 Puerto Real, Cádiz, Spain

\section{Supporting Information}

ABSTRACT: The work described herein is a continuation of our initial studies on the supercritical fluid extraction (SFE) with $\mathrm{CO}_{2}$ of bioactive substances from Helianthus annuus L. var. Arianna. The selected SFE extract showed high activity in the wheat coleoptile bioassay, in Petri dish phytotoxicity bioassays, and in the hydroponic culture of tomato seeds. Chromatographic fractionations of the extracts and a spectroscopic analysis of the isolated compounds showed 52 substances belonging to 10 different chemical classes, which were mainly sesquiterpene lactones, diterpenes, and flavonoids. Heliannuol M (31), helivypolides $\mathrm{K}$ and $\mathrm{L}(36,37)$, and helieudesmanolide B (38) are described for the first time in the literature. Metabolites have been tested in the etiolated wheat coleoptile bioassay with good results in a noteworthy effect on germination. The most active compounds were also tested on tomato seeds, heliannuol A (30) and leptocarpin (45) being the most active, with values similar to those of the commercial herbicide.

KEYWORDS: Helianthus annuus L., supercritical carbon dioxide, bioactive compounds, sesquiterpene lactones, heliannuol, flavonoids, cytotoxicity and phytoxicity bioassays

\section{INTRODUCTION}

The agronomic importance of sunflower (Helianthus annuus L., Asteraceae), together with its well-documented allelopathic activity, which was first reported in $1931,{ }^{1}$ has led to the extensive study of this species from a chemical point of view. Numerous studies have been carried out on the isolation of sunflower constituents with biological activity, with special emphasis placed on phytotoxicity. Most of these studies were performed using aqueous extracts from leaves and in a few cases extracts obtained with nonpolar solvents. The number and variety of isolated compounds shows the complexity of these extracts and the ability of sunflower to produce secondary metabolites. These compounds include sesquiterpenes, diterpenes, sesquiterpene lactones, triterpenes, sterols, flavonoids, coumarins, phenolics, and two new sesquiterpene skeletons: heliannuols and heliespirones. Many of these compounds show phytotoxic activity, even at low concentrations, and this indicates that they could be implicated in the allelopathic activity of sunflower. ${ }^{2-12}$

Extractions have been carried out in an effort to mimic natural conditions, but optimization has not been performed to obtain the most active component. In conventional extraction methods, such as hydrodistillation (steam distillation), Soxhlet extraction, and solvent extraction, there are very few parameters that can be adjusted to control the selectivity of the extraction processes. Therefore, the development of alternative extraction techniques with better selectivity and efficiency is highly desirable. The high price of organic solvents and increasing concern over environmental factors also drive the development of new processing techniques. In the field of natural products, microwave-assisted extraction, accelerated solvent extraction, and supercritical fluid extraction (SFE) require smaller amounts of organic solvents. Of these approaches, SFE is an alternative that does not have any of the negative aspects associated with traditional organic solvents. ${ }^{13}$ Under optimal conditions, SFE offers effective, reproducible, and fast extractions. This technique has been proven to produce equivalent or better results than Soxhlet extraction, solvent extraction, sonication, and accelerated solvent extraction. ${ }^{14,15}$ Among the SFEs, extraction with $\mathrm{SCF}-\mathrm{CO}_{2}$ has received the most attention because of its numerous advantages, broad range of application, and ease of handling, ${ }^{16}$ which is based on its moderate critical temperature $\left(31.3{ }^{\circ} \mathrm{C}\right)$ and pressure (72.9 atm). Carbon dioxide is a gas at room temperature, and this has the advantage that once the extraction is complete and the system is decompressed, the $\mathrm{CO}_{2}$ can be removed to a large extent without leaving residues, thus yielding a solvent-free extract. ${ }^{17}$

Optimization of a SFE procedure is a complex process due to the number of parameters involved: pretreatment of samples, extraction time, pressure, temperature, flow, tapping technique, and supercritical fluid composition. ${ }^{18}$ Each factor can also have a marked effect on the extraction efficiency. ${ }^{19,20}$ This technique is normally performed with pure $\mathrm{CO}_{2}$ or with $\mathrm{CO}_{2}$ in conjunction with a cosolvent. ${ }^{21}$ Time fractionation has become a very useful alternative to improve the selectivity of SFE. In this approach the separation of the solutes extracted from the plant matrix is achieved in two or more separators in series,

Received: May 6, 2015

Revised: June 18, 2015

Accepted: June 25, 2015

Published: July 7, 2015 
which are set at different temperatures and with decreasing pressures. $^{22}$ This technique has been used for the separation of bioactive compounds from herbs, plants, and food industry byproducts as well as for samples for algae and microalgae with different ranges of bioactivities, including antibacterial, antifungal, antiviral, and antioxidant. ${ }^{23}$

With the aforementioned concepts in mind, we performed the bioguided optimization of the leaf extraction on three varieties of sunflower (Stella, Hillian, and Arianna) using $\mathrm{CO}_{2}$ as a supercritical solvent in an effort to obtain an extract with the highest possible activity. ${ }^{24-28}$

The aims of the study presented here were to isolate and structurally characterize the components of this most active extract. Furthermore, the activities of these compounds were measured to identify those responsible for the activity. It was envisaged that this study would provide a better understanding of the bioactivity of sunflower extracts and indicate the possibility of their future use in applications such as weed control.

\section{MATERIALS AND METHODS}

General Experimental Procedures. Infrared (IR) spectra $(\mathrm{KBr})$ were recorded on a Fourier transform infrared (FT-IR) Spectrum 1000 spectrophotometer (PerkinElmer, Waltham, MA, USA). Nuclear magnetic resonance (NMR) spectra were acquired on 400, 500, and $600 \mathrm{MHz}$ spectrometers (Agilent, Palo Alto, CA, USA). Chemical shifts are given in parts per million with respect to residual ${ }^{1} \mathrm{H}$ signals of $\mathrm{CHCl}_{3}-d_{1}(\delta 7.25)$, and ${ }^{13} \mathrm{C}$ signals are referenced to the solvent signal $(\delta$ 77.00). Optical rotations were determined at room temperature on a model 241 polarimeter (PerkinElmer) (on the sodium D line). HRMS were obtained on a Synapt G2 UPLC-QTOF ESI mass spectrometer (Waters, Milford, MA, USA). Column chromatography was carried out on silica gel $0.060-0.200,60 \mathrm{~A}$, from Acros Organics (Geel, Belgium). Thin layer chromatography was carried out on TLC silica gel 60 F245 aluminum sheets. Compounds were visualized under $\mathrm{UV}_{254 / 366}$ light and by spraying with $\mathrm{H}_{2} \mathrm{SO}_{4} /$ $\mathrm{H}_{2} \mathrm{O} / \mathrm{HOAc}(4: 16: 80 \mathrm{v} / \mathrm{v} / \mathrm{v})$ followed by heating at $80^{\circ} \mathrm{C}$. HPLC was carried on a HPLC chromatograph (Merck-Hitachi L, Tokyo, Japan), and solvents were eluted by four-channel pumps (Elite LaChrom L2130 ) with flow rates of $1 \mathrm{~mL} / \mathrm{min}$ for analytical columns and $3 \mathrm{~mL} /$ min for semipreparative columns and with IR detection (Elite LaChrom RI L-2490). The HPLC columns employed were a semipreparative column (Luna $10 \mu \mathrm{m}$, silica (2) $100 \AA$, $250 \mathrm{~mm} \times$ $10 \mathrm{~mm}$ i.d., $10 \mu \mathrm{m}$, with a Security Guard SemiPrep Cartridge silica 10 $\times 10 \mathrm{~mm}$; Phenomenex, Torrance, CA, USA) and an analytical column (Luna $5 \mu \mathrm{m}$, silica (2) $100 \AA \AA$, $250 \mathrm{~mm} \times 4.60 \mathrm{~mm}$ i.d., $5 \mu \mathrm{m}$, with an Analytical Security Guard Cartridge System; Phenomenex, Torrance, CA, USA). The extractions and fractionations for the supercritical fluid extraction with $\mathrm{CO}_{2}$ (SFE) were carried out in equipment supplied by Thar Technology (model SF2000; Pittsburgh, PA, USA).

Chemicals. Chloroform, $n$-hexane, methanol, dichloromethane, ethyl acetate, and acetone (HPLC grade) Hipersolv Chromanorm for HPLC were obtained from VWR International (Radnor, PA, USA). Carbon dioxide (Abelló Linde, S.A., Barcelona, Spain) was used as the supercritical solvent. MagniSolv chloroform- $d_{1}$ (deuteration degree minimum 99.8\%) for NMR spectroscopy was obtained from Merck (Darmstadt, Germany).

Plant Material. Leaves of $H$. annuus L. var. Arianna were collected manually in June 2009 during the third growth stage of the plant ${ }^{29}$ (plants $1.2 \mathrm{~m}$ tall with flowers, 1 week before harvest), because it has been found that at this stage the plant shows greater phytotoxicity. These leaves were provided by Rancho de la Merced, Agricultural Research Station (CIFA), Junta de Andalucia, Jerez de la Frontera, Spain. The moisture of the leaves after harvesting was $65 \%$. Samples were dried on blotting paper at room temperature $\left(25 \pm 1^{\circ} \mathrm{C}\right)$ until a constant weight was reached.
Extraction Fractionation and Isolation. Dried and ground leaves $(75.5 \mathrm{~g})$ were extracted in equipment supplied by Thar Tecnology (model SF2000), and this included an extraction vessel (capacity of $2 \mathrm{~L}$ ) and a high-pressure pump with a maximum flow rate of $200 \mathrm{~g} / \mathrm{min}$ of carbon dioxide (P200 model). Two cyclonic separators $(500 \mathrm{~mL}$ each $)$ connected in series allowed the periodic discharge of extracted material during the SFE process. A pressure regulating valve allowed different conditions to be applied to the separators. The extractions (fractionation process) conducted under the best extraction conditions ${ }^{28}$ gave the best results in terms of yield and bioactivities (cytotoxicity and phytotoxicity bioassays). The conditions used in the extractor were $55^{\circ} \mathrm{C}$ and $400 \mathrm{bar}$ and in the separators, $90 \mathrm{bar}$ and $40{ }^{\circ} \mathrm{C}$ in the first separator $\mathrm{S} 1$ and atmospheric conditions in the second separator S2. The flow rate measured for the supercritical carbon dioxide was $20 \mathrm{~g} / \mathrm{min}$ during $3 \mathrm{~h}$. The extracts were collected in acetone and concentrated under vacuum at the same temperature as the extraction. The dried extract $(7.0 \mathrm{~g})$ obtained in the second separator S2 by the fractionation process (SFE), which was free of chlorophylls, was chromatographed on a column $(116 \mathrm{~cm} \times 15 \mathrm{~cm}$ i.d., $1300 \mathrm{~g}$ of silica gel $60 \mathrm{~A}$ ) using $n$-hexane/ethyl acetate mixtures of increasing polarity from 5 to $100 \%$ in ethyl acetate with a $10 \%$ increase each time and finishing with $100 \%$ methanol $(500 \mathrm{~mL}$ of each polarity). This procedure afforded seven fractions after comparison by TLC: A $(95: 5 \mathrm{v} / \mathrm{v}, 664.8 \mathrm{mg}), \mathrm{B}(90: 10 \mathrm{v} / \mathrm{v}, 343 \mathrm{mg}), \mathrm{C}(80: 20 \mathrm{v} / \mathrm{v}$, $1.2 \mathrm{~g}), \mathrm{D}(70: 30 \mathrm{v} / \mathrm{v}, 349.6 \mathrm{mg}), \mathrm{E}(50: 50 \mathrm{v} / \mathrm{v}, 2.5 \mathrm{~g}), \mathrm{F}(20: 80 \mathrm{v} / \mathrm{v}$, $644.3 \mathrm{mg}), \mathrm{G}(100 \%$ ethyl acetate, $158 \mathrm{mg})$, and $\mathrm{H}(100 \% \mathrm{MeOH}$, $63.9 \mathrm{mg}$ ).

The data of fractionation and isolation of compounds from fractions $\mathrm{B}-\mathrm{F}$ are presented in detail in the Supporting Information (Fractionation and Isolation S3).

Spectroscopic Data for the New Compounds. Heliannuol M (31): colorless oil; $[\alpha]{ }_{\mathrm{D}}^{25}=-11.0^{\circ}\left(c 1.0, \mathrm{CHCl}_{3}\right)$; IR $\nu_{\max }(\mathrm{KBr})$ $\mathrm{cm}^{-1} 3350(\mathrm{OH}), 1620$ (aromatic $\left.\mathrm{C}=\mathrm{C}\right), 1265(\mathrm{C}-\mathrm{O}-\mathrm{C}) ;{ }^{1} \mathrm{H}$ NMR $\left(\mathrm{CDCl}_{3} 400 \mathrm{MHz}\right)$ data, see Table $1 ;{ }^{13} \mathrm{C}$ NMR $\left(\mathrm{CDCl}_{3} 125\right.$ $\mathrm{MHz}$ ) data, see Table 1; HREIMS $\mathrm{m} / z$ (rel intensity) $266.1512[\mathrm{M}]^{+}$ (calcd 266.1518); EIMS $m / z 266[\mathrm{M}]^{+}, 248\left[\mathrm{M}-\mathrm{H}_{2} \mathrm{O}\right]^{+}, 235[\mathrm{M}-$ $\left.\mathrm{CH}_{2}-\mathrm{OH}\right]^{+}$.

Helivypolide $\mathrm{K}(36)$ : colorless oil; $[\alpha]{ }_{\mathrm{D}}^{25}=-30.0^{\circ}\left(c 1.0, \mathrm{CHCl}_{3}\right)$; IR $\nu_{\max }(\mathrm{KBr}) \mathrm{cm}^{-1} 3466(\mathrm{OH}), 1779(\alpha, \beta$-unsaturated $\gamma$-lactone), $1710\left(\alpha, \beta\right.$-unsaturated ester); ${ }^{1} \mathrm{H}$ NMR $\left(\mathrm{CDCl}_{3}, 600 \mathrm{MHz}\right)$ data, see Table 2; ${ }^{13} \mathrm{C}$ NMR $\left(\mathrm{CDCl}_{3}, 125 \mathrm{MHz}\right)$ data, see Table 2; positive-ion HREITOFMS $m / z$ 375.1441 $[\mathrm{M}+\mathrm{H}]^{+}$(calcd for $[\mathrm{M}+\mathrm{H}]^{+}$, 375.1444); EIMS $m / z$ (rel intensity) $375[\mathrm{M}+\mathrm{H}]^{+}, 292\left[\mathrm{M}-\mathrm{C}_{5} \mathrm{H}_{7} \mathrm{O}\right.$ $+\mathrm{H}]^{+}, 83\left[\mathrm{C}_{4} \mathrm{H}_{7} \mathrm{O}\right]^{+}$.

Table 1. ${ }^{1} \mathrm{H}$ NMR (600 MHz) and ${ }^{13} \mathrm{C}(125 \mathrm{MHz})$ Spectroscopic Data for Compound 31 in $\mathrm{CDCl}_{3}$

\begin{tabular}{llc} 
no. & \multicolumn{1}{c}{$\delta_{\mathrm{H}}$ multi $(\mathrm{J}$ in $\mathrm{Hz})$} & $\delta_{\mathrm{C}}$ \\
\hline 1 & & 138.0 \\
2 & & 151.5 \\
3 & $6.70 \mathrm{~s}$ & 123.5 \\
4 & & 122.1 \\
5 & & 149.8 \\
6 & $6.53 \mathrm{~s}$ & 115.9 \\
7 & $2.90 \mathrm{ddq}(7.2,5.0,3.0)$ & 38.5 \\
$8 \alpha$ & $1.86 \mathrm{dddd}(13.5,4.05 .0,3.6)$ & 31.8 \\
$8 \beta$ & $1.72 \mathrm{dddd}(13.5,10.6,3.0,3.2)$ & \\
$9 \alpha$ & $2.02 \mathrm{dddd}(13.2,11.1,10.6,3.6)$ & 25.2 \\
$9 \beta$ & $1.91 \mathrm{dddd}(13.2,3.2,4.0,1.5)$ & \\
10 & $3.48 \mathrm{dd}(11.1,1.5)$ & 89.0 \\
11 & & 73.8 \\
12 & $1.21 \mathrm{~s}$ & 20.1 \\
13 & $3.93 \mathrm{~d}(11.1)$ & 67.3 \\
$13^{\prime}$ & $3.52 \mathrm{~d}(11.1)$ & \\
14 & $1.26 \mathrm{~d}(7.2)$ & 18.6 \\
15 & $2.17 \mathrm{~s}$ & \\
& &
\end{tabular}


Table 2. ${ }^{1} \mathrm{H}$ NMR (600 MHz) and ${ }^{13} \mathrm{C}(125 \mathrm{MHz})$ Spectroscopic Data for Compounds 36 and 37 and Helivypolide $\mathrm{F}^{12}$ in $\mathrm{CDCl}_{3}$

\begin{tabular}{|c|c|c|c|c|c|c|}
\hline \multirow[b]{2}{*}{ no. } & \multicolumn{2}{|l|}{36} & \multicolumn{2}{|l|}{37} & \multicolumn{2}{|l|}{ helivypolide $\mathrm{F}^{12}$} \\
\hline & $\delta_{\mathrm{H}}$ multi $(J$ in $\mathrm{Hz})$ & $\delta_{\mathrm{C}}$ & $\delta_{\mathrm{H}}$ multi $(J$ in $\mathrm{Hz})$ & $\delta_{\mathrm{C}}$ & $\delta_{\mathrm{H}}$ multi $(J$ in $\mathrm{Hz})$ & $\delta_{\mathrm{C}}$ \\
\hline 1 & $6.51 \mathrm{~d}(13.2)$ & 151.6 & $6.34 \mathrm{~d}(12.8)$ & 147.5 & $6.32 \mathrm{~d}(13.1)$ & 150.0 \\
\hline 2 & $6.05 \mathrm{~d}(13.2)$ & 126.8 & $5.99 \mathrm{~d}(12.8)$ & 127.4 & $5.99 \mathrm{~d}(13.1)$ & 127.3 \\
\hline 3 & & 195.5 & & 202.2 & & 189.4 \\
\hline 4 & & 60.4 & & 69.0 & & 143.8 \\
\hline 5 & $3.74 \mathrm{~d}(10.3)$ & 80.4 & $3.73 \mathrm{~d}(10.2)$ & 78.8 & $4.54(9.8)$ & 79.3 \\
\hline 6 & $5.36 \mathrm{dd}(10.3,9.9)$ & 74.8 & $5.47 \mathrm{dd}(10.2,9.9)$ & 75.3 & 5.11 dd $(9.8,9.7)$ & 76.2 \\
\hline 7 & 3.42 dddd $(9.9,1.7,3.2,3.5)$ & 47.2 & 3.37 dddd $(9.9,1.8,3,1,3.4)$ & 45.2 & 3.41dddd $(9.7,1.7,3.2,3.4)$ & 47.1 \\
\hline 8 & 5.81 ddd $(1.76,3.5,2.6)$ & 65.3 & 5.78 ddd $(1.8,3.5,2.5)$ & 66.5 & 5.75 ddd $(3.8,2.8,1.7)$ & 65.4 \\
\hline $9 \alpha$ & $2.40 \mathrm{dd}(3.5,15.5)$ & 46.8 & $2.34 \mathrm{dd}(3.5,15.3)$ & 46.2 & $2.34 \mathrm{dd}(2.8,15.4)$ & 46.8 \\
\hline $9 \beta$ & $2.20 \mathrm{dd}(2.6,15.5)$ & & $2.23 \mathrm{dd}(2.5,15.3)$ & & $2.16 \mathrm{dd}(3.8,15.4)$ & \\
\hline 10 & & 81.1 & & 80.8 & & 80.4 \\
\hline 11 & & 133.0 & & 134.1 & & 134.5 \\
\hline 12 & & 168.5 & & 167.3 & & 168.3 \\
\hline $13 \mathrm{a}$ & $5.68 \mathrm{~d}(3.2)$ & 123.3 & $5.67 \mathrm{~d}(3.1)$ & 122.6 & $5.62 \mathrm{~d}(3.2)$ & 122.6 \\
\hline $13 b$ & $6.36 \mathrm{~d}(3.5)$ & & $6.33 \mathrm{~d}(3.4)$ & & $6.35 \mathrm{~d}(3.4)$ & \\
\hline 14 & $1.50 \mathrm{~s}$ & 32.9 & $1.41 \mathrm{~s}$ & 29.9 & $1.40 \mathrm{~s}$ & 32.9 \\
\hline 15 & $3.30 \mathrm{~d}(6.5)$ & 52.4 & $3.70 \mathrm{~d}(4.4)$ & 64.2 & $5.60 \mathrm{~d}(1.5)$ & 128.5 \\
\hline $15^{\prime}$ & $3.13 \mathrm{~d}(6.5)$ & & $3.71 \mathrm{~d}(4.4)$ & & $6.40 \mathrm{~d}(1.5)$ & \\
\hline $1^{\prime}$ & & 165.8 & & 166.1 & & 166.1 \\
\hline $2^{\prime}$ & & 125.8 & & 126.4 & & 122.4 \\
\hline $3^{\prime}$ & $6.17 \mathrm{qq}(7.2,1.5)$ & 141.6 & $6.16 \mathrm{qq}(7.1,1.5)$ & 141.3 & $6.15 \mathrm{qq}(7.2,1.5)$ & 141.3 \\
\hline $4^{\prime}$ & $1.98 \mathrm{dq}(1.5,7.2)$ & 15.3 & $1.97 \mathrm{dq}(7.1,1.5)$ & 16.1 & $1.98 \mathrm{dq}(7.2,1.5)$ & 15.5 \\
\hline $5^{\prime}$ & $1.80 \mathrm{dq}(1.5,1.5)$ & 20.5 & $1.82 \mathrm{dq}(1.5,1.5)$ & 20.1 & $1.80 \mathrm{dq}(1.5,1.5)$ & 20.5 \\
\hline
\end{tabular}

Helivypolide L (37): colorless oil; $[\alpha]_{\mathrm{D}}^{25}=-21.7^{\circ}\left(c 1.0, \mathrm{CHCl}_{3}\right)$; IR $\nu_{\max }(\mathrm{KBr}) \mathrm{cm}^{-1} 3468(\mathrm{OH}), 1780(\alpha, \beta$-unsaturated $\gamma$-lactone), $1710\left(\alpha, \beta\right.$-unsaturated ester); ${ }^{1} \mathrm{H}$ NMR $\left(\mathrm{CDCl}_{3}, 600 \mathrm{MHz}\right)$ data, see Table 2; ${ }^{13} \mathrm{C}$ NMR $\left(\mathrm{CDCl}_{3}, 125 \mathrm{MHz}\right)$ data, see Table 2; positive-ion HREITOFMS $m / z$ 393.1544 $[\mathrm{M}+\mathrm{H}]^{+}$(calcd for $[\mathrm{M}+\mathrm{H}]^{+}$, 393.1549); EIMS $m / z$ (rel intensity) $393[\mathrm{M}+\mathrm{H}]^{+}, 310\left[\mathrm{M}-\mathrm{C}_{5} \mathrm{H}_{7} \mathrm{O}\right.$ $+\mathrm{H}]^{+}, 83\left[\mathrm{C}_{4} \mathrm{H}_{7} \mathrm{O}\right]^{+}$.

Helieudesmanolide B (38): colorless oil; $[\alpha]{ }_{\mathrm{D}}^{25}=-33.6^{\circ}$ (c 1.0, $\left.\mathrm{CHCl}_{3}\right)$; IR $\nu_{\max }(\mathrm{KBr}) \mathrm{cm}^{-1} 3410(\mathrm{OH}), 1776(\alpha, \beta$-unsaturated $\gamma$ lactone), 1700 ( $\alpha, \beta$-unsaturated ester); ${ }^{1} \mathrm{H}$ NMR $\left(\mathrm{CDCl}_{3}, 600 \mathrm{MHz}\right)$ data, see Table $3 ;{ }^{13} \mathrm{C}$ NMR $\left(\mathrm{CDCl}_{3}, 125 \mathrm{MHz}\right)$ data, see Table 3; positive-ion HREITOFMS $m / z 363.1806[\mathrm{M}+\mathrm{H}]^{+}$(calcd for $[\mathrm{M}+$ $\mathrm{H}]^{+}$, 363.1808).

Bioassays. Wheat coleoptile bioassays as well as phytotoxicity bioassays on tomato seeds were performed according to previously described procedures. ${ }^{30}$

Molecular Modeling. Three-dimensional models for the tested chemicals were obtained from PM3 calculations performed by Hyperchem 7.01 software (Hypercube Inc., Gainesville, FL, USA; 2000).

\section{RESULTS AND DISCUSSION}

The results indicated that the best extraction yields and activity profiles were obtained from the Arianna variety with an extraction pressure and temperature of 400 bar and $55{ }^{\circ} \mathrm{C}$, respectively, at a flow rate of $20 \mathrm{~g} / \mathrm{min}$ for $3 \mathrm{~h}$. A cascade fractionation was carried out in an effort to increase the biological activity of the extract obtained under these conditions. $^{28}$ This process involved the stepwise precipitation of the extracts obtained in the process. This goal was achieved by modification of the density of $\mathrm{CO}_{2}$ through changes in the pressure and temperature in the separators. In this way, the compounds that were least soluble in the supercritical solvent precipitated in the first separator, whereas more soluble materials remained in the second separator.
Table 3. ${ }^{1} \mathrm{H}$ NMR $(600 \mathrm{MHz})$ and ${ }^{13} \mathrm{C}(125 \mathrm{MHz})$ Spectroscopic Data for Compound 38 in $\mathrm{CDCl}_{3}$

\begin{tabular}{llr}
\hline no. & $\delta_{\mathrm{H}}$ multi $(J \mathrm{in} \mathrm{Hz})$ & $\delta_{\mathrm{C}}$ \\
\hline 1 & $3.70 \mathrm{dd}(1.9,11.6)$ & 76.3 \\
$2 \alpha$ & $2.74 \mathrm{dd}(1.9,12.1)$ & 46.2 \\
$2 \beta$ & $2.55 \mathrm{dd}(11.6,12.1)$ & \\
3 & $2.58 \mathrm{dd}(11.3,6.7)$ & 44.5 \\
4 & $1.60 \mathrm{dd}(11.3,11.1)$ & 50.6 \\
5 & $4.46 \mathrm{dd}(11.1,10.8)$ & 78.2 \\
6 & $2.85 \mathrm{ddd}(10.8,1.8,3.3)$ & 52.9 \\
7 & $5.82 \mathrm{dd}(1.8,2.5,3.7)$ & 65.1 \\
8 & $2.48 \mathrm{dd}(2.5,15.1)$ & 40.9 \\
$9 \alpha$ & $1.61 \mathrm{dd}(3.7,15.1)$ & \\
$9 \beta$ & & 41.9 \\
10 & & 133.6 \\
11 & $5.50 \mathrm{~d}(2.9)$ & 169.3 \\
12 & $6.19 \mathrm{~d}(3.3)$ & 120.2 \\
$13 \mathrm{a}$ & $1.27 \mathrm{~s}(6.7)$ & 13.8 \\
$13 \mathrm{~b}$ & $1.31 \mathrm{~d}(6.7)$ & 13.7 \\
14 & & 166.7 \\
15 & $6.12 \mathrm{qq}(7.0,1.5)$ & 126.8 \\
$1^{\prime}$ & $1.99 \mathrm{dq}(7.0,1.5)$ & 140.1 \\
$2^{\prime}$ & $1.86 \mathrm{dq}(1.5,1.5)$ & 20.6 \\
$3^{\prime}$ & & 13.8 \\
$4^{\prime}$ & & \\
$5^{\prime}$ & & \\
\end{tabular}

Better bioactivity profiles, yields, and separation of chlorophylls were obtained when the first separator was run at a pressure of $90 \mathrm{bar}$ and a temperature of $40{ }^{\circ} \mathrm{C}$ with atmospheric conditions in the second separator. The extract obtained in the second separator (chlorophyll free) showed inhibition levels in the coleoptile bioassay of around $60 \%$ at the 
<smiles>CCCCC/C=C/C/C=C/C=CC(=O)O</smiles>

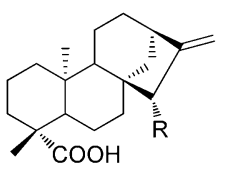

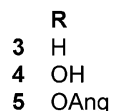<smiles>CC1(C(=O)O)CCCC23CCCC1C2CCC(=O)C3</smiles>

9<smiles>C=C(CCCC(C)CCCC(C)CCCC(C)C)C(O)CO</smiles><smiles>CC/C=C\C/C=C/C/C=C/C=CC(=O)O</smiles>

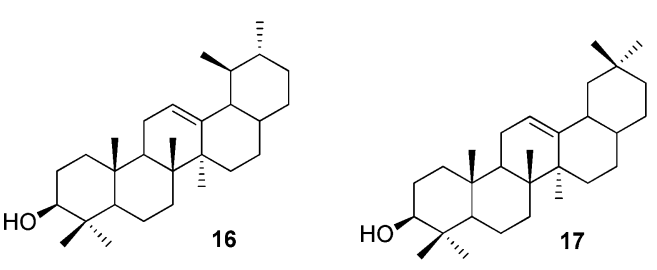

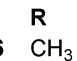
$7 \mathrm{CH}_{2} \mathrm{OH}$

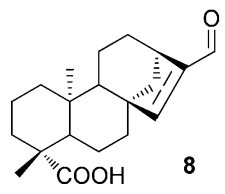<smiles>[R7]C12CCC3C4CCCC(C)(C(=O)O)C4CCC3(CC1)C2</smiles>
$\begin{array}{lll} & \mathrm{R}_{1} & \mathrm{R}_{2} \\ \mathbf{1 1} & \mathrm{CH}_{2} \mathrm{OH} & \mathrm{H} \\ \mathbf{1 2} & \mathrm{H} & \mathrm{CH}_{2} \mathrm{OH} \\ \mathbf{1 3} & \mathrm{CH}_{3} & \mathrm{OH} \\ \mathbf{1 4} & \mathrm{OH} & \mathrm{CH}_{3}\end{array}$<smiles>CCC(/C=C/[C@@H](C)C1CCC2C3CC=C4CC(O)CC[C@]4(C)C3CC[C@@]21C)C(C)C</smiles>

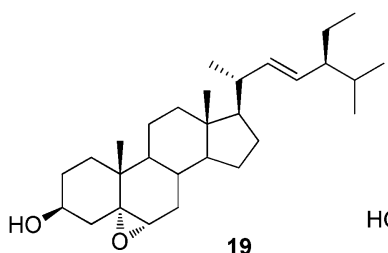<smiles>CCC(/C=C/[C@@H](C)C1CCC2C3CC4OC45CC(CC[C@@]21C)C3(C)CC[C@H](O)C5)C(C)C</smiles><smiles>O=C1C=Cc2cc(O)c(O)cc2C1</smiles>

Figure 1. Compounds 1-21 isolated from dried leaves of $H$. annuus L. var. Arianna extracted with pure supercritical $\mathrm{CO}_{2}$.

highest concentration tested $(1.0 \mathrm{mg} / \mathrm{mL})$ and $30 \%$ at the most dilute concentration $(0.075 \mathrm{mg} / \mathrm{mL})$. Phytotoxicity was also analyzed using two different bioassays, namely, a phytotoxicity bioassay carried out on tomato, lettuce, onion, and watercress seeds and a bioassay under hydroponic conditions on tomato. ${ }^{28}$ The results were compared with those obtained with the commercial herbicide Logran. The data obtained on tomato showed the highest levels of activity. The extract showed root growth inhibitions of $70 \%$ at $0.8 \mathrm{mg} / \mathrm{mL}$ and $43 \%$ at $0.2 \mathrm{mg} /$ $\mathrm{mL}$ (the limiting dilutions tested in this bioassay). Germination of tomato was also affected by this extract with values similar to the standard herbicide, that is, in the range of $78-57 \%$ for the three dilutions studied $(0.8,0.4$, and $0.2 \mathrm{mg} / \mathrm{mL})$. The bioassay under hydroponic conditions corroborated the activity observed in the Petri dish bioassay. Significant growth inhibition $(>60 \%)$ of stems and roots of the tomato plants was obtained at $0.8 \mathrm{mg} / \mathrm{mL}$.

Appropriate conditions for the fractionation of the bioactive extract $(7 \mathrm{~g})$ by CC and HPLC were identified. The chromatographic separation of fractions $\mathrm{B}-\mathrm{F}$ led to the isolation of 52 compounds (Figures 1-3), and these were grouped together as 10 different chemical classes depending on their carbon skeleton: 2 fatty acids, 2 monoterpenes, 4 bisnorsesquiterpenes, 2 sesquiterpenes, 14 sesquiterpene lactones, 13 diterpenes, 2 triterpenes, 3 sterols, 8 flavonoids, 1 coumarin, and 1 lignan. The isolated compounds were identified from their spectroscopic data by comparison with the data reported in the literature as presented in the Supporting Information (Identified Compounds S8).

Compounds 6, 11, 19-21, 23, 41, and 48 were isolated from $H$. annuus for the first time. Heliannuol M (31) was previously isolated by our research group from $H$. annuus variety $\mathrm{SH}$ $222,^{31}$ and its spectral data are being reported for the first time. Helivypolide K (36), helivypolide L (37), and helieudesmanolide B (38) were characterized as new compounds.

Compound 31 was isolated as a colorless oil. The HRMS contained a peak at $\mathrm{m} / z 266.1512$, which is consistent with a molecular formula of $\mathrm{C}_{15} \mathrm{H}_{22} \mathrm{O}_{4}$. The ${ }^{1} \mathrm{H}$ NMR and ${ }^{13} \mathrm{C}$ NMR (Table 1) data are very similar to those previously reported for heliannuol D. ${ }^{11}$ The only difference observed is the lack of the singlet assigned to one methyl group located on C-11 and the appearance of doublet signals with coupling constants of $J=$ $11.1 \mathrm{~Hz}$ at $\delta 3.93$ and 3.52, which are assigned to a hydroxymethylene group located on one of these carbons.

This assignment is fully supported by the ${ }^{1} \mathrm{H} \mathrm{NMR}$ and ${ }^{13} \mathrm{C}$ NMR spectra as well as by COSY, HMBC, and HSQC experiments. The relative stereochemistries of C-7 and C-10 can be inferred by comparison with the chemical shifts and coupling constants of protons on the heterocycle of heliannuol $D$, which are established as $7 R$ and $10 R .^{11}$ Thus, the similarities between the signals of these two compounds indicate that the 

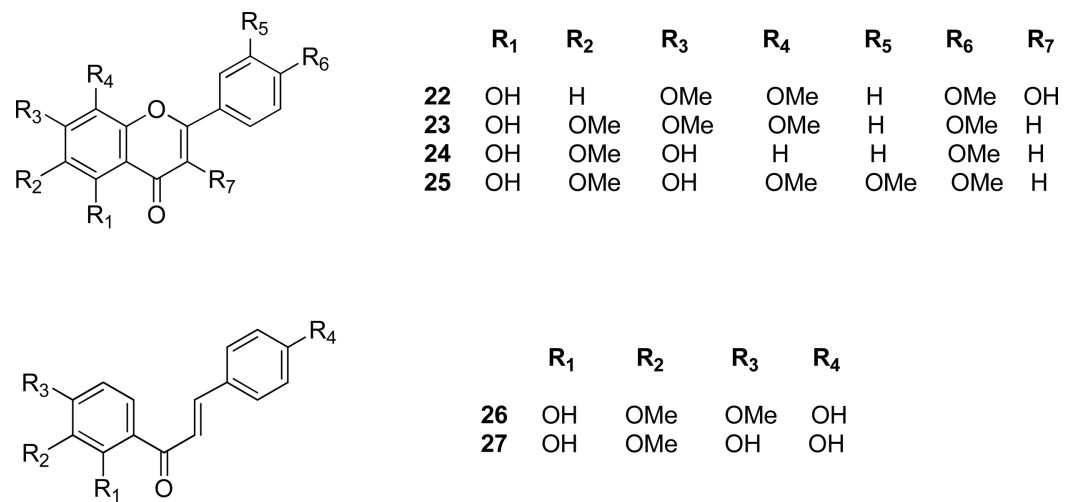<smiles>[R]c1ccc(C2CC(=O)c3ccc([R])c([R])c3O2)cc1</smiles>

$\begin{array}{llll} & \mathbf{R}_{\mathbf{1}} & \mathbf{R}_{\mathbf{2}} & \mathbf{R}_{\mathbf{3}} \\ \mathbf{2 8} & \mathrm{OMe} & \mathrm{OMe} & \mathrm{OH} \\ \mathbf{2 9} & \mathrm{OH} & \mathrm{OMe} & \mathrm{OH}\end{array}$
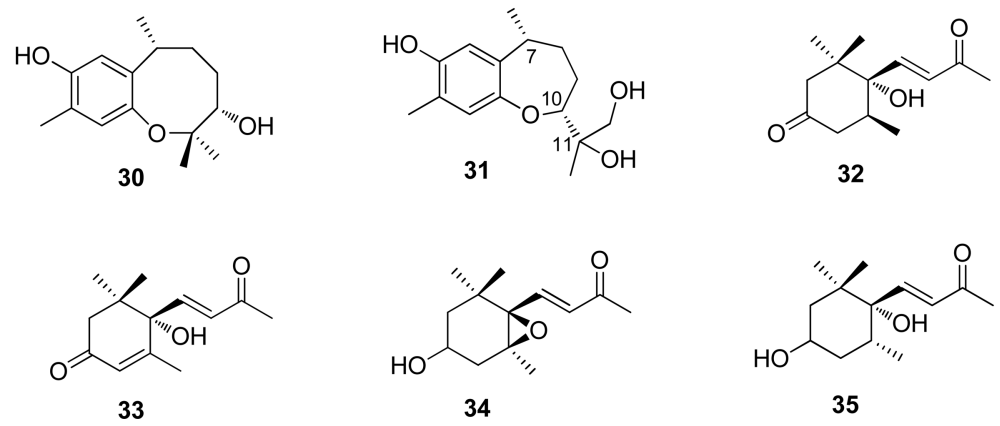

Figure 2. Compounds 22-35 isolated from dried leaves of $H$. annuus L. var. Arianna extracted with pure supercritical $\mathrm{CO}_{2}$.

structure of 31 can be established as 5,11,13-trihydroxy-7R,10Rheliannane, which is named heliannuol $\mathrm{M}^{31}$

Compound 36 was isolated as a colorless oil. The positive ion mode HREITOFMS contained a peak at $m / z$ 375.1441 [M $+\mathrm{H}]^{+}$. This result, together with the EIMS fragment ions at $m /$ $z 375[\mathrm{M}+\mathrm{H}]^{+}, 292\left[\mathrm{M}-\mathrm{C}_{5} \mathrm{H}_{7} \mathrm{O}+\mathrm{H}\right]^{+}$, and $83\left[\mathrm{C}_{4} \mathrm{H}_{7} \mathrm{O}\right]^{+}$ and the ${ }^{1} \mathrm{H}$ and ${ }^{13} \mathrm{C}$ NMR data (Table 2), is consistent with the molecular formula $\mathrm{C}_{20} \mathrm{H}_{22} \mathrm{O}_{7}$ (calcd for $[\mathrm{M}+\mathrm{H}]^{+}$, 375.1444). The ${ }^{1} \mathrm{H}$ NMR spectrum of this compound was very similar to that of helivypolide $\mathrm{F}^{12}$ (Table 2), which was previously isolated from $H$. annuus, except for an upfield shift for $\mathrm{H}-15$, which appears instead of the exocyclic-methylene signals. Comparison of the ${ }^{1} \mathrm{H}$ NMR and ${ }^{13} \mathrm{C}$ NMR spectra supports a structure very similar to that of helivypolide $\mathrm{F}$ with some modifications at C-4 and C-15.

The absence of a signal assignable to $\mathrm{H}-4$, as well as the presence in the ${ }^{1} \mathrm{H}$ NMR spectrum of two isolated doublets at $\delta$ 3.30 and $3.13\left(\mathrm{~d}, J_{15 \alpha, 15 \beta}=6.5 \mathrm{~Hz}\right.$ ) for $\mathrm{H}-15 \alpha$ and $\mathrm{H}-15 \beta$, and the chemical shifts of the signals corresponding to C-4 $(\delta 60.4)$ and $\mathrm{C}-15\left(\delta\right.$ 52.4) in the ${ }^{13} \mathrm{C}$ NMR spectrum indicated the presence of an epoxide between $\mathrm{C}-4$ and $\mathrm{C}-15$. This was confirmed by a g-HMBC experiment, in which the coupling of C-4 with $\mathrm{H}-2, \mathrm{H}-5, \mathrm{H}-15$, and $\mathrm{H}-15^{\prime}$ was observed (Supporting Information S18). The $\alpha$-orientation of $\mathrm{H}-5$ was corroborated by an NOE effect observed in the corresponding bidimensional 2D-NOESY spectrum with $\mathrm{H}-15^{\prime}$ and with $\mathrm{H}-7$ and $\mathrm{H}-8$ (Figure 4). Thus, 36 was established as $8 \beta$-angeloyloxy-5 $\beta, 10 \beta$ -
epoxy-4,15-epoxy-3-oxo-germacrane-1Z,11(13)-dien-6 $\alpha, 12$ olide and was named helivypolide $\mathrm{K}$.

Compound 37 was isolated as a colorless oil. The positiveion HREITOFMS showed an $m / z$ of $393.1544[\mathrm{M}+\mathrm{H}]^{+}$ which, in conjunction with the ${ }^{1} \mathrm{H}$ NMR data (Table 2), is consistent with the molecular formula $\mathrm{C}_{20} \mathrm{H}_{24} \mathrm{O}_{8}$ (calcd for $[\mathrm{M}$ $+\mathrm{H}]^{+}$, 393.1549). The ${ }^{1} \mathrm{H}$ NMR spectrum was essentially the same as that described above for compound 36 (Figure 5), but with slight differences in some of the chemical shifts. The differences are due to the shielding experienced by H-1 $(\delta 6.34$; $\delta \Delta=0.16)$ and $\mathrm{H}-2(\delta 5.99 ; \delta \Delta=0.15)$ and the deshielding of H-15' $(\delta 3.71 ; \delta \Delta=-0.41)$ and $\mathrm{H}-15(\delta 3.70 ; \delta \Delta=-0.57)$. These findings indicate a modification of the methylene group at $\mathrm{C}-15$ with respect to compound 36 , and once again the signal for $\mathrm{H}-4$ was absent and two doublets were observed for $\mathrm{H}-15$ and $\mathrm{H}-15^{\prime}$ at $\delta 3.70$ and 3.71, (d, $\left.J_{15,15^{\prime}}=4.4 \mathrm{~Hz}\right)$ in the ${ }^{1} \mathrm{H}$ NMR spectrum. On the other hand, the changes in the ${ }^{13} \mathrm{C}$ NMR spectrum for C-15 $(\delta 66.5)$ and C-4 $(\delta 69.0)$ (Table 2$)$ indicated the presence of hydroxyl groups at C-15 and C-4, which correspond to the opened epoxide derivative of 36 . The g-HMBC experiment showed coupling between H-5 ( $\delta$ 3.73) and C-15 ( $\delta 66.5)$, and this confirmed the position of a hydroxyl group at C-15. This finding substantiates the significant hydrogen bond obtained in the minimum energy conformation calculations for this compound using PM3 (Figure 6). Thus, 37 was established as $8 \beta$-angeloyloxy$5 \beta, 10 \beta$-epoxy-4,15-dihydroxy-3-oxogermacrane-1Z,11(13)dien-6 $\alpha, 12$-olide, which was named helivypolide $\mathrm{L}$. 
<smiles>C=C1C(=O)O[C@H]2[C@H]1[C@]1(C)O[C@@]1(C)C[C@]2(C)OC(=O)/C(C)=C\C</smiles>

36

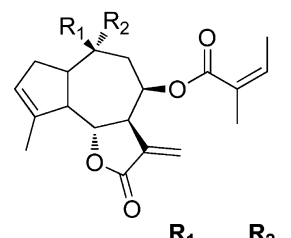

$\begin{array}{lll} & \mathbf{R}_{\mathbf{1}} & \mathbf{R}_{\mathbf{2}} \\ \mathbf{3 9} & \mathrm{OH} & \mathrm{CH}_{3} \\ \mathbf{4 0} & \mathrm{CH}_{3} & \mathrm{OH}\end{array}$

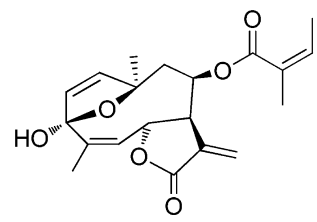

43<smiles>C=C1CC(C(C[C@](C)(O)/C=C\C(=O)CO)OC(=O)/C(C)=C\C)COC1=O</smiles>

47<smiles>C=C1CCC(O)C2(C)CCC(C)[C@H](O)C12</smiles>

50

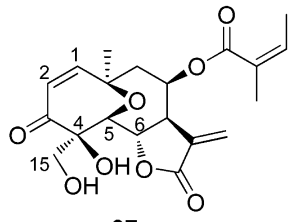

37<smiles>C=C1C(=O)OC2C3C(C)=CC(=O)C3=C(C)CC(OC(=O)/C(C)=C\C)C12</smiles>

41<smiles>C=C1C(=O)OC2C(COC(=O)/C(C)=C\C)C(=O)OC12</smiles>

44<smiles>C=C1C(=O)OC2/C=C(/CO)C(=O)C3OC3C(C)(O)CC(O)C12</smiles><smiles>CC1(C)CC(O)C[C@H]2OC(=O)C=C21</smiles>

51

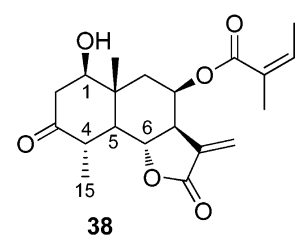<smiles>C=C1C(=O)O[C@H]2C1C[C@@H](O)C(=C)C1CCC(=C)C12</smiles>

42

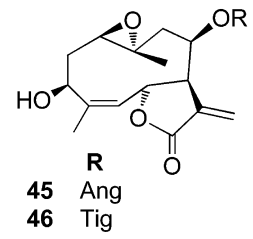

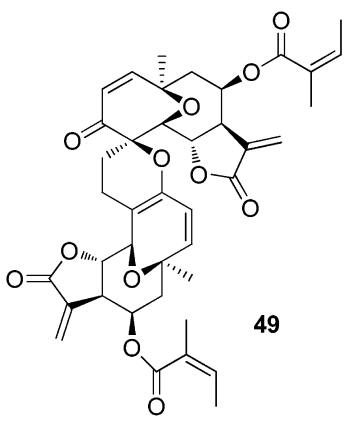<smiles>COc1cc([C@H]2OC[C@@H]3[C@@H](c4ccc(O)c(OC)c4)OC[C@H]23)ccc1O</smiles>

Figure 3. Compounds 36-52 isolated from dried leaves of $H$. annuus L. var. Arianna extracted with pure supercritical $\mathrm{CO}_{2}$.

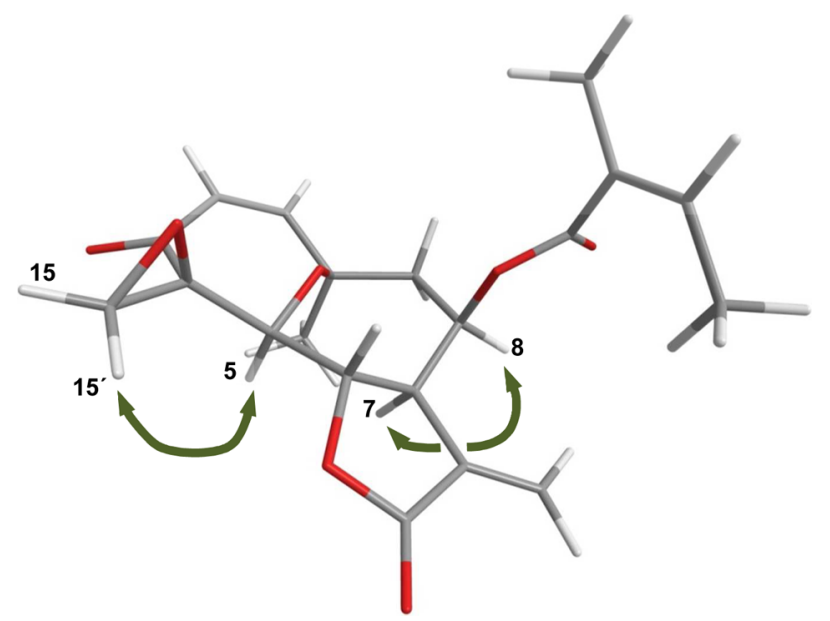

Figure 4. NOE effects observed for the most stable conformer of helivypolide K (36).
Compound 38 was isolated as a colorless oil. The positive ion mode HREITOFMS contained an $[\mathrm{M}+\mathrm{H}]^{+}$ion at $\mathrm{m} / z$ 363.1806, which is consistent with the molecular formula $\mathrm{C}_{20} \mathrm{H}_{26} \mathrm{O}_{6}$ (calcd for $\left.[\mathrm{M}+\mathrm{H}]+{ }^{+}, 363.1808\right)$. The ${ }^{1} \mathrm{H}$ NMR spectrum (Table 3 ) showed signals characteristic of a sesquiterpene lactone with a eudesmane skeleton very similar to that of helieudesmanolide $A,{ }^{12}$ previously isolated from $H$. annuus, except for a doublet due to a methyl group at $\delta 1.31$ $\left(J_{4,15}=6.75 \mathrm{~Hz}\right)$ on $\mathrm{C}-4$, corresponding to $\mathrm{H}-15$, and the absence of a signal for $\mathrm{H}-3$. In this case the eudesmane skeleton showed a typical methyl signal at $\delta 1.27(\mathrm{H}-14)$ and a doublet of doublets at $\delta 4.46$ assigned to H-6 $\left(J_{5,6}=11.1 \mathrm{~Hz}, J_{6,7}=10.8\right.$ $\mathrm{Hz})$. The ${ }^{1} \mathrm{H}$ NMR-2D-COSY experiment showed that H-5 $(\delta$ $1.60)$ was coupled with $\mathrm{H}-4\left(\delta 2.58\right.$, dd, $\left.J_{4,5}=11.3 \mathrm{~Hz}\right)$ and $\mathrm{H}$ $15\left(\delta 1.31, \mathrm{~d}, J_{4,15}=6.7 \mathrm{~Hz}\right)$. Signals observed at $\delta 3.70(\mathrm{dd}$, $\left.J_{1,2 \alpha}=1.9 \mathrm{~Hz}, J_{1,2 \beta}=11.6 \mathrm{~Hz}\right), \delta 2.55\left(\mathrm{dd}, J_{2 \beta, 2 \alpha}=12.1 \mathrm{~Hz}, J_{1,2 \beta}\right.$ $=11.6 \mathrm{~Hz})$, and $\delta 2.74\left(\mathrm{dd}, J_{2 \alpha, 2 \beta}=12.1, J_{1,2 \alpha}=1.9 \mathrm{~Hz}\right)$ were assigned to $\mathrm{H}-1, \mathrm{H}-2 \beta$, and $\mathrm{H}-2 \alpha$, respectively, and other proton coupling was not observed, which suggests that the C-3 


\section{Helivypolida K (36)}

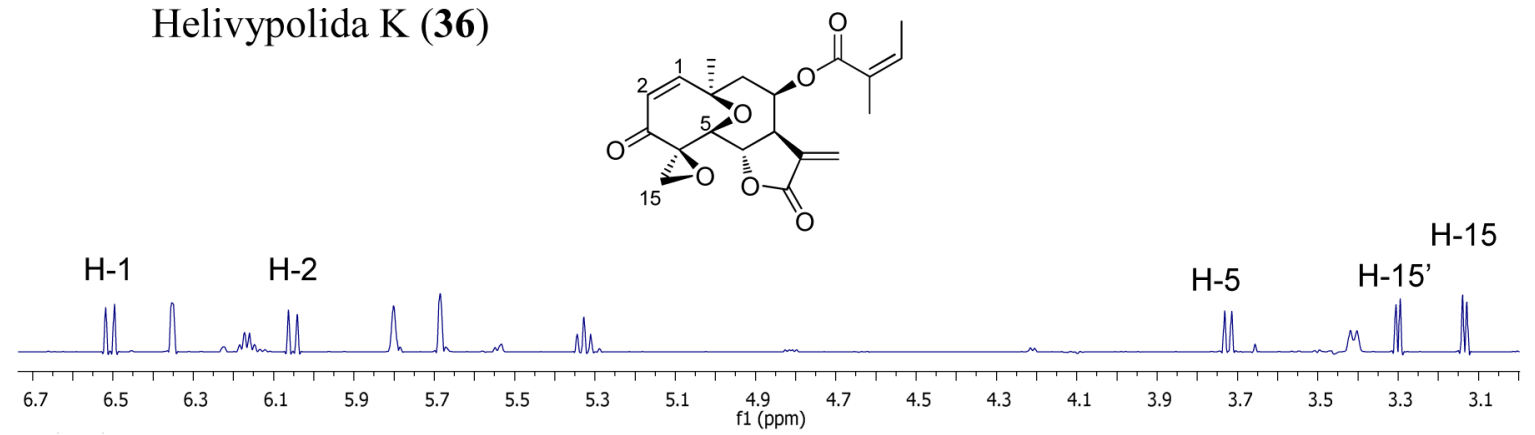

Helivypolida L (37)

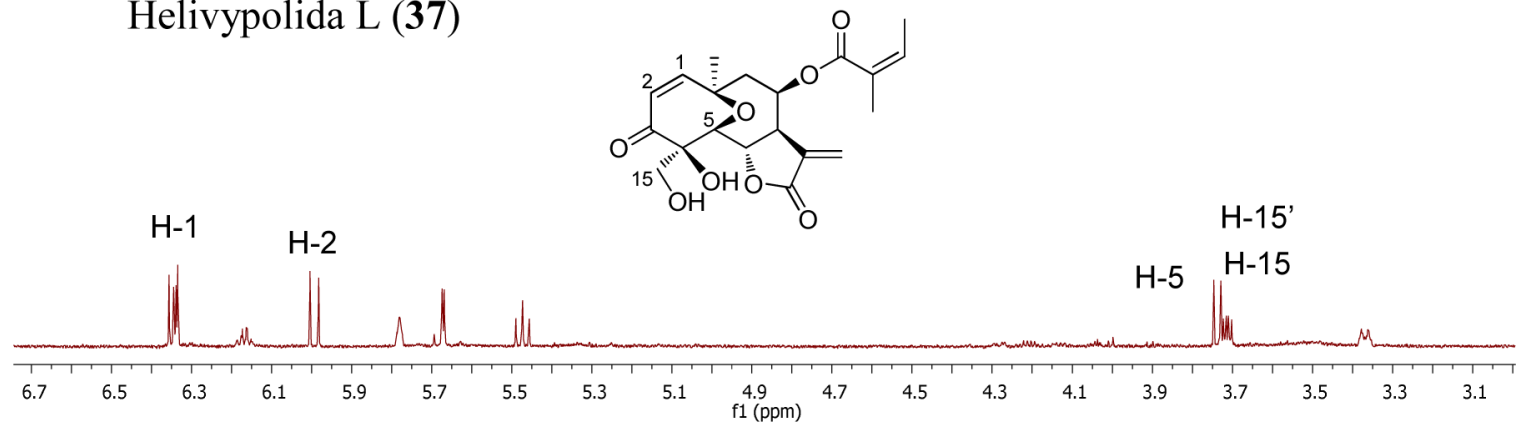

Figure 5. ${ }^{1} \mathrm{H}$ NMR comparison between helivypolide K (36) and helivypolide L (37).

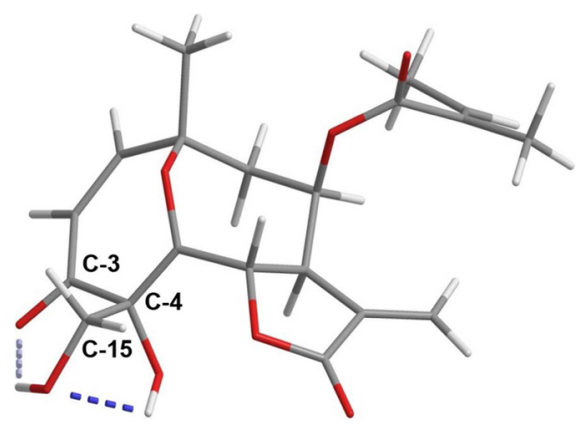

Figure 6. Significant hydrogen bond obtained in minimum energy calculations on the conformation of helivypolide L (37) using PM3.

position is occupied. The chemical shifts of $\mathrm{C}-1$ and $\mathrm{C}-2$ in the ${ }^{13} \mathrm{C}$ NMR spectrum at $\delta 76.3(\mathrm{CH})$ and $\delta 46.2\left(\mathrm{CH}_{2}\right)$, respectively, indicate that there is a hydroxyl group bonded to $\mathrm{C}-1$. The ${ }^{13} \mathrm{C}$ NMR spectrum (Table 3 ) contained 20 signals, and the signal at $\delta 207.5$ confirmed the presence of a ketone group, which is located at C-3 due to the absence of a signal assignable to $\mathrm{H}-3$ in the ${ }^{1} \mathrm{H}$ NMR spectrum and the correlations observed in the g-HMBC experiment between protons at $\delta 2.55(\mathrm{H}-2 \beta), \delta 2.74(\mathrm{H}-2 \alpha), \delta 2.58(\mathrm{H}-4) \delta 1.60$ $(\mathrm{H}-5)$, and $\delta 1.31(\mathrm{H}-15)$ with the carbon at $\delta 207.5(\mathrm{C}-3)$ (Supporting Information S23).

The orientation of H-5 was established on the basis of the coupling constant with H-6 $\left(J_{5,6}=11.1 \mathrm{~Hz}\right)$ and assuming a $\beta$ orientation for H-6 and an $\alpha$-orientation for $\mathrm{H}-7$ and $\mathrm{H}-8$. The relative stereochemistry of the molecule was determined on the basis of NOE effects observed in the 2D-NOESY experiment. Thus, NOE effects were observed for proton $\mathrm{H}-5$ with $\mathrm{H}-1$ and $\mathrm{H}-8$ and for $\mathrm{H}-14$ with $\mathrm{H}-4$ and $\mathrm{H}-6$. The latter indicates an orientation $\alpha$ to the methyl at $\mathrm{C}-4(\mathrm{H}-15)$ (Figure 7). Thus, 38 was established as $8 \beta$-angeloyloxyl- $\beta$-hydroxy-3-oxo-eudes- mane-11(13)-en-6 $\alpha, 12$-olide, and this compound was named helieudesmanolide $\mathrm{B}$.

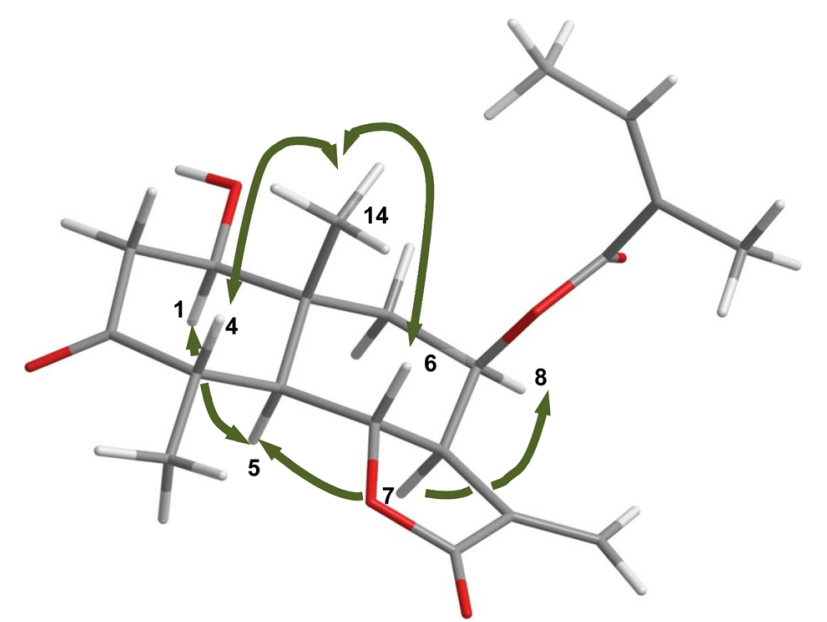

Figure 7. NOE effects observed for the most stable conformer of helieudesmanolide B (38) by PM3 calculations.

The bioactivities of 12 diterpenes (3-14), 1 coumarin (21), 8 flavonoids (22-29), 2 heliannuols (30 and 31), 4 bisnorsesquiterpenes (32-35), and 11 sesquiterpene lactones (39-49) were assessed in the wheat coleoptile bioassay in a concentration range from $10^{-3}$ to $10^{-5} \mathrm{M}$ (except for compounds $13,27,31,43$, and 46 , which had a concentration limit of $3 \times 10^{-4} \mathrm{M}$ ). The results obtained are summarized in Figures 8 and 9 .

The remaining compounds, $\mathbf{1 5}, \mathbf{1 8}, \mathbf{3 6 - 3 8}$, and 50-52, were not tested due to the low amounts obtained. Compounds 16, 17,19 , and 20 were not assessed because they were obtained as mixtures. The bioassay employed is rapid $(24 \mathrm{~h})$ and sensitive 


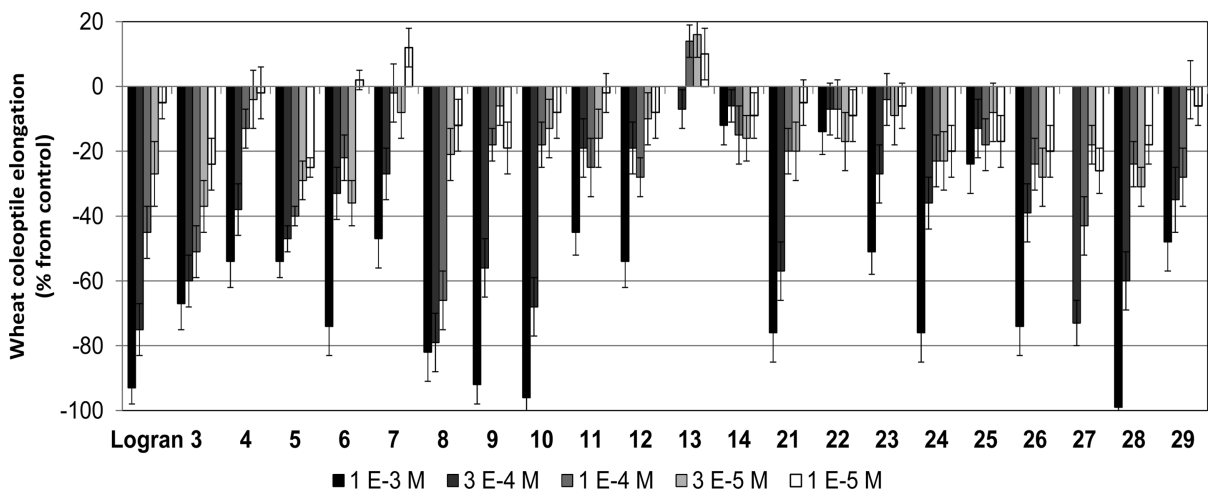

Figure 8. Effects of compounds 3-29 from the bioactive fraction of the extract of $H$. annuus L. var. Arianna on the elongation of etiolated wheat coleoptiles. Values are expressed as percentage difference from control.

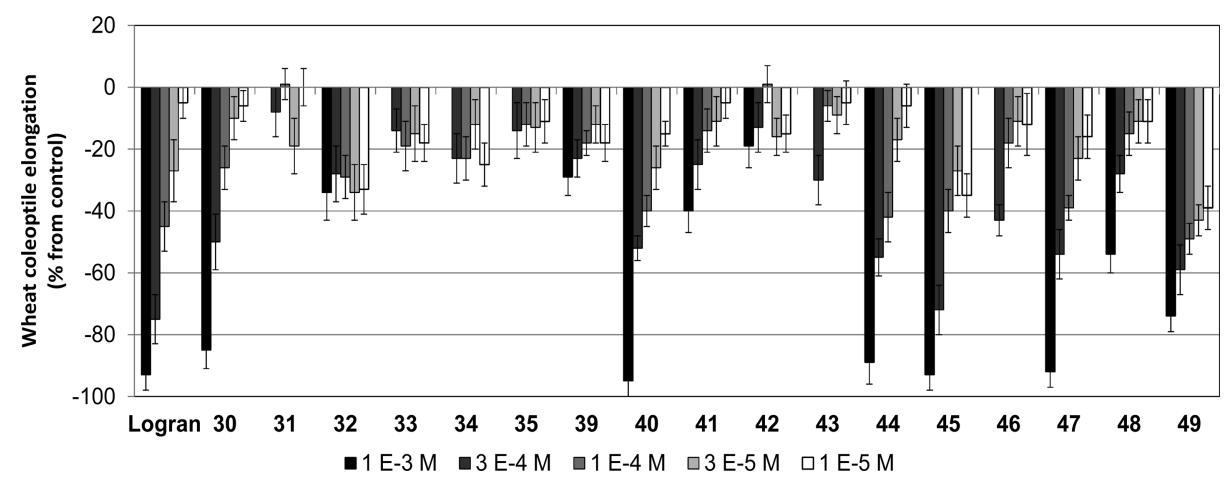

Figure 9. Effects of compounds 30-49 from the bioactive fraction of the extract of H. annuus L. var. Arianna on the elongation of etiolated wheat coleoptiles. Values are expressed as percentage difference from control.

to a wide range of bioactive substances including plant growth regulators, herbicides, antimicrobials, mycotoxins, and assorted pharmaceuticals. $^{32}$

The activities of some of these compounds have been evaluated previously using the etiolated wheat coleoptile ${ }^{33}$ and standard target species (STS $)^{34}$ bioassays in the concentration range of $10^{-4}-10^{-9} \mathrm{M}^{8,35}$ To obtain a more complete picture of the compounds isolated in this work, we have reconsidered that, as better candidates for a natural herbicide model, the compounds should be tested in bioassays with a range of activities with the following dilutions: $10^{-3}, 3 \times 10^{-4}, 10^{-4}, 3 \times$ $10^{-5}$, and $10^{-5} \mathrm{M}$ for both bioassays. The commercial herbicide Logran was used as an internal reference.

Diterpene compounds 3-14 showed significant inhibitory activity on coleoptile elongation, except diterpenes 13 and $\mathbf{1 4}$. The highest inhibitory activities of these diterpenes were shown by 8,9 , and 10 , with values $>80 \%$ at $10^{-3} \mathrm{M}(82,92$, and $96 \%$ inhibition, respectively). Some of these values are higher than that of the commercial herbicide Logran at this concentration (Figure 8). These compounds were also active at the second concentration $\left(3 \times 10^{-4} \mathrm{M}\right)(79,56$, and $68 \%$ inhibition, respectively), and compound 8 was even active at the third $\left(10^{-4} \mathrm{M}\right.$ with an inhibition of $\left.66 \%\right)$, but these compounds had a little effect at the highest dilutions. Compounds 3 and $\mathbf{5}$ were less active than those outlined above, but they showed higher persistence with dilution and a better effect was observed at the high concentration for compound $3(68 \%)$ in comparison to compound 5 (53\%). On the other hand, compound 6 showed a high inhibition at $10^{-3} \mathrm{M}(73 \%)$, but this decreased with dilution.
Coumarin 21 also showed high inhibitory activity at the two highest concentrations $\left(10^{-3}\right.$ and $\left.3 \times 10^{-4} \mathrm{M}\right)$ (76 and $57 \%$ inhibition). Flavonoids 22-29 inhibited coleoptile elongation, and in this series, $\mathbf{2 4}$ and 26-28 had the highest values. These compounds showed high inhibitory activity at the highest concentration $\left(10^{-3} \mathrm{M}\right): 24(76 \%), 26(74 \%), 27(73 \%)$, and 28 (99\%). Even the least active compound had better activity than the commercial herbicide reference at this concentration (Figure 8).

Heliannuol A (30) showed high inhibitory activity on coleoptile elongation at $10^{-3} \mathrm{M}$, with a value of $85 \%$ (very close to the value value of Logran, $93 \%$ ), and at $3 \times 10^{-3}$ (50\%), but the activity decreased significantly with dilution. In contrast, heliannuol M (31) had no effect on coleoptile elongation at any concentration (Figure 9). Bisnorsesquiterpene compounds 3235 showed low inhibitory activities at all concentrations assayed $(<30 \%)$.

Of all sesquiterpene lactones tested (39-49) compounds 40, $44,45,47$, and 49 had the best activity profiles and the highest inhibitory activity on coleoptile elongation (Figure 9). These compounds showed values close to $90 \%$ inhibition at the highest concentration $\left(10^{-3} \mathrm{M}\right): 40$ (95\%), 45 (93\%), 44 $(89 \%)$, and 47 (92\%). These values are similar to that of the commercial herbicide at the same concentration. Compound 49 showed the best inhibitory activity profile of all compounds evaluated and also showed the most persistence with dilution ( $73 \%$ at $10^{-3} \mathrm{M}$ and $39 \%$ at $10^{-5} \mathrm{M}$ ).

Of all the compounds tested on the elongation of etiolated wheat coleoptile, compounds 8-10, 21, 24, 26-28, 30, 40, 44, 45,47 , and 49 were the most active, and they were selected for the evaluation of phytotoxicity on tomato seed growth (except 

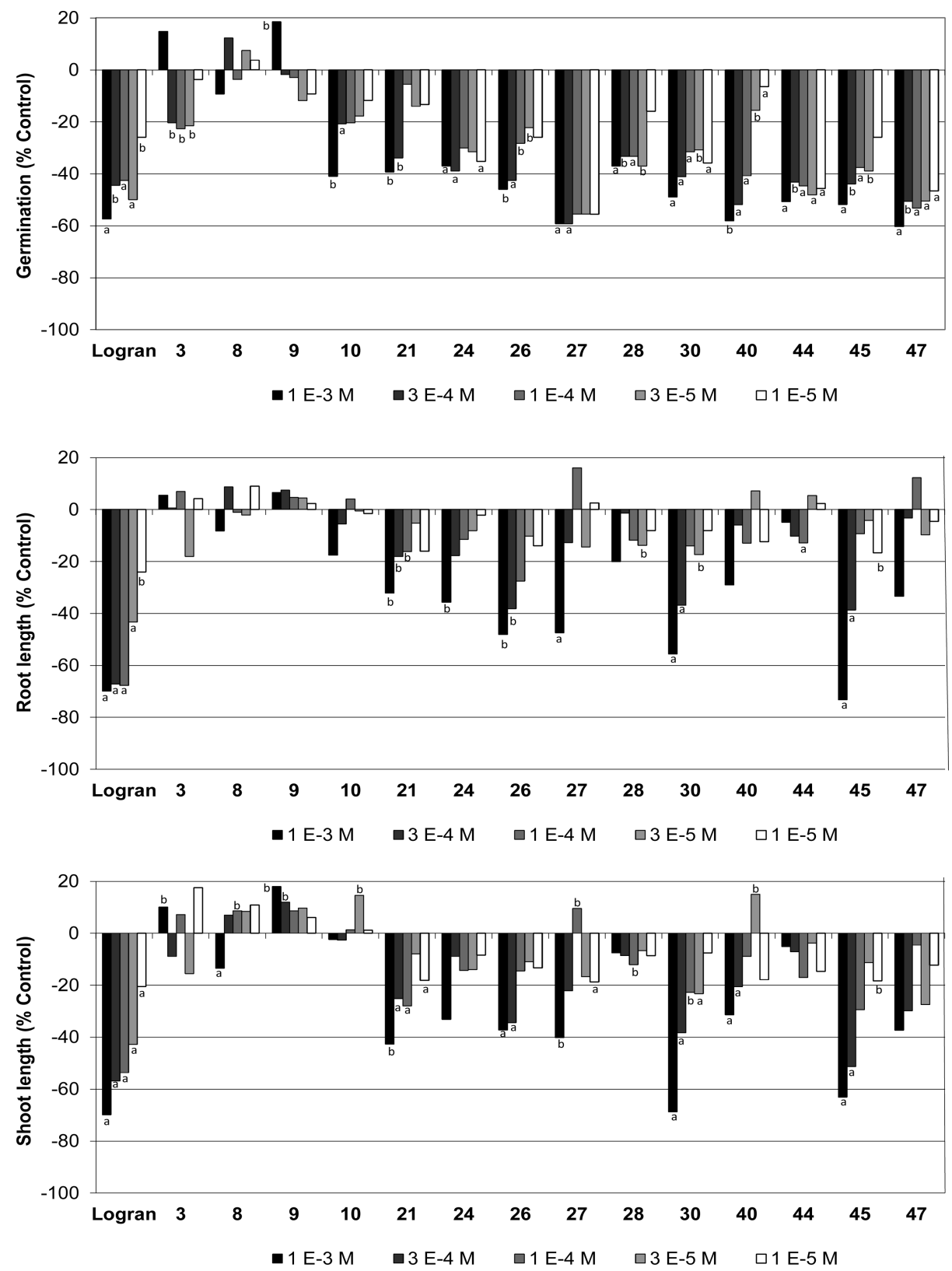

Figure 10. Effects of compounds $3,8-10,21,24,26-28,30,40,44,45$, and 47 from the bioactive fraction of the extract of sunflower $(H$. annuus $\mathrm{L}$. var. Arianna) on L. esculentum seed growth. Values are expressed as percentage difference from control.

for 49 , due to the low amount available) as this was the most sensitive species in previous bioassays with the initial extract. ${ }^{28}$ The commercial herbicide Logran was used as an internal standard. ${ }^{34}$ The results of the bioassay are represented in Figure 10 , where data are presented as percentage differences from the control. The concentrations tested were identical to those in the coleoptile bioassay.

In this phytotoxicity bioassay the most significantly affected parameter was the germination for all compounds assayed, except for diterpenes 3 and 8-10. Coumarin 21, flavonoids 24 and 26-28, heliannuol 30, and sesquiterpene lactones 40, 44, 45, and 47 showed inhibition levels close to that of the herbicide Logran for most dilutions (between 40 and 60\%).

Allelopathy is often demonstrated by testing allelochemical effects on germination. The germination process usually begins with water uptake by the seed (imbibition) and ends with the protrusion of the radicle through the testa. The seed germination test has been a widely used bioassay for the determination of allelopathic activity. ${ }^{36}$ Another important point is that the observed effects varied with the seed tested. Tomato seeds were found to be more sensitive than other species evaluated. This may be due to differences in seed size, seed coat permeability, differential uptake, and metabolism. ${ }^{37}$

Root and shoot length were the variables that were most affected by heliannuol A (30) and the sesquiterpene lactone leptocarpin (45) at the first two concentrations $\left(10^{-3}\right.$ and $3 \times$ $\left.10^{-4} \mathrm{M}\right)$, and they showed inhibitory activity similar to that of the commercial herbicide (70\%).

Heliannuol A (30) was the most active compound on the shoot growth of tomato seeds at the first concentration $\left(10^{-3}\right.$ M) with $70 \%$ inhibition, that is, similar to that of the commercial herbicide. The inhibition of root growth at the same concentration was $56 \%$. Furthermore, this compound had an inhibitory effect on germination at the highest concen- 
trations, with values close to those of the standard herbicide (around 50\%).

This compound belongs to the sesquiterpene family, which has a basic heliannane skeleton typical of such compounds isolated from sunflower, ${ }^{11}$ and it has been reported to have plant growth regulatory activity. ${ }^{10}$ The activity shown by this compound at the dilutions tested in both bioassays carried out in this work and the amount isolated from the extract indicate that its role may be related to the allelopathic behavior shown by this species.

The best results on root growth of tomato seeds at the highest concentration were shown by the sesquiterpene lactone leptocarpin (45) $\left(10^{-3} \mathrm{M}, 73 \%\right.$ inhibition). For this compound, shoot inhibition at $10^{-3} \mathrm{M}$ was $63 \%$. The effect on germination of this seed also reached inhibition values similar to that of Logran at the highest concentrations (50\%).

Sesquiterpene lactones bearing germacranolide and heliangolide backbones along with diterpenes are the most abundant compounds in the genus Helianthus. The activities of these compounds have been related to the presence of the $\alpha$ methylene- $\gamma$-lactone moiety, the presence of an oxygenated group (mainly an angelate ester) at $\mathrm{C}-8$, and/or the different special arrangements that the molecule can adopt. ${ }^{38}$ It seems that the accessibility of groups that can be alkylated plays an important role in the activity of these compounds. Moreover, these compounds have shown a wide spectrum of activities: allelopathic, deterrent, cytotoxic, bacteriacidal, fungicicidal, etc. Some of these activities can be correlated to the ecological roles of the compounds in the plant, but others are mainly characterized by their toxic properties and their ability to bind to important biomolecules. ${ }^{39}$

Furthermore, there are several studies concerning the regulatory activity of sesquiterpene lactones on germination and plant growth. ${ }^{40}$ The observed activity of leptocarpin 45 on the germination and root growth inhibition of Lycopersicon esculentum seeds can be related to the flexibility that this molecule has in comparison to the other sesquiterpene lactones tested (40, 44, and 47) and to the presence of two electrophilic functions, namely, the $\alpha$-methylene- $\gamma$-lactone moiety and the oxirane ring. It can be considered that leptocarpin $\mathbf{4 5}$ is another candidate that one would expect to be involved in defense mechanisms of $H$. annuus.

Annuolide G (40), niveusin B (44), and 15-hydroxy-3dehydrodeoxytifruticin (47) showed low inhibitory effects on root and shoot growth of tomato seeds, but they showed high inhibitory activity on germination, as mentioned above, with values close to that of Logran (at $10^{-3} \mathrm{M}: 58,54$, and $60 \%$ of inhibition for 40,44, and 47, respectively). For this parameter, 44 and 47 showed greater persistence as the activity was retained upon dilution, even at $10^{-5} \mathrm{M}(50 \%)$, when compared to 40, the activity of which decreased markedly in the last two dilutions. It is noteworthy that these heliangolides (44 and 47) have shown antibacterial properties against several organisms, such as P. vulgaris, B. brevis, B. subtilis, and Streptomyces sp., ${ }^{41}$ and they are highly active as fungicides, especially against Eremothecium asbhbyi, ${ }^{42}$ along with leptocarpin 45 , which gave an MIC value as low as $1 \mathrm{ppm}$ for several fungal species. ${ }^{43}$

The compounds that had the smallest effect on the germination and growth of tomato seeds were the diterpenes 3 and 8-10, although these compounds did show good activity in the coleoptile bioassay. These diterpenoids are not usually reported as being phytotoxic agents despite the fact that they constitute a large group of compounds present in the genus
Helianthus. The ecological role of these compounds has been associated more with antifeedant, insecticidal, and deterrent activity. Moreover, some diterpenoids, such as giberrellins, act as important plant hormones that are involved in growth regulation. $^{44}$

Coumarins are defined as stress or defensive metabolites, and their synthesis is usually induced as a response to both biotic and abiotic stress-inducing agents. ${ }^{45}$ The most significant values obtained on tomato seeds by coumarin sculetin (21) were found for the inhibition of germination (39\%) and shoot length (42\%) at a concentration of $10^{-3} \mathrm{M}$, although this compound did exhibit high levels of inhibition in the coleoptile bioassay at higher concentrations $\left(10^{-3}, 3 \times 10^{-3} \mathrm{M}\right)$ with values of 77 and $58 \%$, respectively.

Another large group of compounds that are widely distributed in Helianthus are the flavonoids, but very few of these have been implicated in allelopathy (some chalcones and dihydrochalcones). ${ }^{46}$ These compounds $(\mathbf{2 4}, \mathbf{2 6 - 2 8})$ showed inhibitory effects on tomato seed growth, especially on germination, but they had intermediate effects on shoot and root growth. The structures of chalcones $\mathbf{2 6}$ and $\mathbf{2 7}$ are very similar as they differ only in the presence of an additional methyl group in $\mathbf{2 6}$; however, their activities on germination are quite different. The reason for this variation could be related to the number and positions of free hydroxyl groups. Chalcone kukulkanin B (27) was the most active on germination of the flavonoids tested, and it also showed the best inhibitory activity profile with an average value of $60 \%$ from $10^{-3} \mathrm{M}$ to $10^{-5} \mathrm{M}$ (higher values than the commercial herbicide). The chalcone heliannone A (26) showed inhibition values of around $47 \%$ for the first concentrations $\left(10^{-3}\right.$ and $\left.3 \times 10^{-4} \mathrm{M}\right)$. Compounds 26 and 27 both caused inhibition of shoot (around 40\%) and root growth $(50 \%)$ at the first concentration $\left(10^{-3} \mathrm{M}\right)$. It has been reported that flavonoids and flavones may act as insect attractants or repellents, either playing a defensive role or providing favorable interactions, among other activities. ${ }^{47}$

In conclusion, the results obtained in this study complement the current knowledge of allelopathic behavior shown by sunflower. The new extraction techniques used are environmentally clean and are more effective and selective for the extraction of bioactive natural products. Supercritical fluid extraction is one alternative to supplement or replace the conventional separation systems because the energy yields and separation efficiency are both good. In this study a bioactive extract of medium polarity was selectively obtained using $\mathrm{CO}_{2}$ as the supercritical solvent. A total of 52 compounds were isolated from this extract, and these belong to 10 different chemical skeletons. Of these, the majority were sesquiterpene lactones (three of them are described for the first time in the literature), diterpenes, and flavonoids.

Because the initial extract showed good activity profiles in the coleoptile bioassay, ${ }^{28} 38$ pure compounds isolated from this fraction were again evaluated in the same bioassay, and $>50 \%$ of these showed better results than the initial extract, with inhibition values in some cases $>90 \%$.

Good results were obtained for the initial extract in a previously reported phytotoxicity bioassay on tomato seeds in terms of percentage inhibition of germination and shoot and root length compared with Logran. ${ }^{28}$ Good results were also obtained for the pure compounds, with a remarkable effect observed on germination in particular. The exceptions to this trend were the diterpene compounds. With regard to the development of this seed, sesquiterpene $\mathbf{3 0}$ (heliannuol A) and 
sesquiterpene lactone 45 (leptocarpin) showed the strongest inhibitory effects, with activities similar to that of the commercial herbicide.

It is clear that allelopathic behavior is a very complex phenomenon and, hence, it cannot be assumed that a single compound, or even a small number of them, can be identified as being responsible for this behavior in all cases. The wide variety and activity of compounds found in the sunflower extract studied, both here and previously, makes, it conceivable that they are implicated in these interactions. Synergistic or additive interactions are usually not comparable to the activity of a single active compound, unless such a compound already participates in the combination. The specific structural factors that operate and determine the activity of a particular combination of compounds remains unclear. The same holds true for the combined effect; the character of such an effect cannot be predicted on the basis of an individual compound acting alone. In some cases, a noninhibitory concentration of a specific compound inhibits growth when this compound acts additively or synergistically with other allelochemicals that are present, and such joint action is the most common situation.

As a consequence, any studies that focus on the understanding of allelopathic interactions in Helianthus spp. should involve as many structures as be possible; otherwise, the study will be incomplete. On the other hand, the SFE technique has proven to be a useful tool to obtain bioactive extracts that contain a number of bioactive compounds from an agricultural byproduct. These extracts and compounds could be used in the future for weed control in an environmentally safe way within the context of sustainable agriculture.

\section{ASSOCIATED CONTENT}

\section{S Supporting Information}

${ }^{1} \mathrm{H},{ }^{13} \mathrm{C}$ of new compounds, 31 and 36-38; enlargement gHMBC spectra of compounds 36 and 38 ; additional information on fractionation, isolation and identification of compounds. The Supporting Information is available free of charge on the ACS Publications website at DOI: 10.1021/ acs.jafc.5b02261.

\section{AUTHOR INFORMATION}

\section{Corresponding Author}

*(F.A.M.) Phone: +34 956012770. Fax: +34 956016193. Email: famacias@uca.es.

\section{Funding}

This research was supported by the Ministerio de Economía y Competitividad (MINECO) (Project AGL2013-42238-R) and Consejería de Economía Innovación y Ciencia, Junta de Andalucía (Project DP12-TEP-725).

\section{Notes}

The authors declare no competing financial interest.

\section{ACKNOWLEDGMENTS}

We gratefully acknowledge the staff at the Rancho de la Merced Research and Formation Center (Junta de Andalucia, Jerez de la Frontera, Spain) for providing the raw material.

\section{DEDICATION}

In memory of Professor George R. Waller, Jr.

\section{ABBREVIATIONS USED}

Ang, angelate; Tigl, tiglate

\section{REFERENCES}

(1) Macias, F. A. Allelopathy in the search for natural herbicide models. ACS Symp. Ser. 1995, No. 582, 310-329.

(2) Macias, F. A.; Varela, R. M.; Torres, A.; Molinillo, J. M. G. Allelopathic studies on cultivar species. 3. Potential allelopathic guaianolides from cultivar sunflower leaves, var. SH-222. Phytochemistry 1993, 34, 669-674.

(3) Macias, F. A.; Molinillo, J. M. G.; Torres, A.; Varela, R. M.; Castellano, D. Allelopathic studies in cultivar species. Part 9. Bioactive flavonoids from Helianthus annuus cultivars. Phytochemistry 1997, 45, 683-687.

(4) Macias, F. A.; Varela, R. M.; Torres, A.; Oliva, R. M.; Molinillo, J. M. G. Allelopathic studies in cultivar. Part 10. Bioactive norsesquiterpenes from Helianthus annuus with potential allelopathic activity. Phytochemistry 1998, 48, 631-636.

(5) Macias, F. A.; Varela, R. M.; Torres, A.; Molinillo, J. M. G. Allelopathic studies in cultivar species. II. Heliespirone A. The first member of a novel family of bioactive sesquiterpenes. Tetrahedron Lett. 1998, 39, 427-430.

(6) Macias, F. A.; Varela, R. M.; Torres, A.; Molinillo, J. M. G. Allelopathic studies in cultivar species. 12. Heliannuol E. A novel bioactive sesquiterpene of the heliannane family. Tetrahedron Lett. 1999, 40, 4725-4728.

(7) Macias, F. A.; Varela, R. M.; Torres, A.; Molinillo, J. M. G. New bioactive plant heliannuols from cultivar sunflower leaves. J. Nat. Prod. 1999, 62, 1636-1639.

(8) Macias, F. A.; Oliva, R. M.; Varela, R. M.; Torres, A.; Molinillo, J. M. G. Allelopathic studies in cultivar species. 14. Allelochemicals from sunflower leaves cv. Peredovick. Phytochemistry 1999, 52, 613-621.

(9) Macias, F. A.; Lopez, A.; Varela, R. M.; Torres, A.; Molinillo, J. M. G. Bioactive lignans from a cultivar of Helianthus annuus. J. Agric. Food Chem. 2004, 52, 6443-6447.

(10) Macias, F. A.; Varela, R. M.; Torres, A.; Molinillo, J. M. G.; Fronczek, F. R. Allelopathic studies on cultivar species. 2. Novel sesquiterpene from bioactive fractions of cultivar sunflowers. Tetrahedron Lett. 1993, 34, 1999-2002.

(11) Macias, F. A.; Molinillo, J. M. G.; Varela, R. M.; Torres, A.; Fronczek, F. R. Structural elucidation and chemistry of a novel family of bioactive sesquiterpenes: heliannuols. J. Org. Chem. 1994, 59, 82618266.

(12) Macias, F. A.; Fernandez, A.; Varela, R. M.; Molinillo, J. M. G.; Torres, A.; Alves, P. L. C. A. Sesquiterpene lactones as allelochemicals. J. Nat. Prod. 2006, 69, 795-800.

(13) Mannila, M.; Koistinen, J.; Vartiainen, T. Comparison of SFE with Soxhlet in the analyses of PCDD/PCDFs and PCBs in sediment. J. Environ. Monit. 2002, 4, 1047-1053.

(14) Berg, B. E.; Lund, H. S.; Kringstad, A.; Kvernheim, A. L. Routine analysis of hydrocarbons, $\mathrm{PCB}$ and $\mathrm{PAH}$ in marine sediments using supercritical $\mathrm{CO}_{2}$ extraction. Chemosphere 1998, 38, 587-599.

(15) Hartonen, K.; Bowadt, S.; Dybdahl, H. P.; Nylund, K.; Sporring, S.; Lund, H.; Oreld, F. Nordic laboratory intercomparison of supercritical fluid extraction for the determination of total petroleum hydrocarbon, polychlorinated biphenyls and polycyclic aromatic hydrocarbons in soil. J. Chromatogr. A 2002, 958, 239-248.

(16) Marr, R.; Gamse, T. Use of supercritical fluids for different processes including new developments - a review. Chem. Eng. Process. 2000, 39, 19-28.

(17) Beckman, E. J. Supercritical and near-critical $\mathrm{CO}_{2}$ in green chemical synthesis and processing. J. Supercrit. Fluids 2004, 28, 121191.

(18) Bravi, E.; Perretti, G.; Montanari, L.; Favati, F.; Fantozzi, P. Supercritical fluid extraction for quality control in beer industry. $J$. Supercrit. Fluids 2007, 42, 342-346.

(19) Bravi, M.; Bubbico, R.; Manna, F.; Verdone, N. Process optimization in sunflower oil extraction by supercritical $\mathrm{CO}_{2}$. Chem. Eng. Sci. 2002, 57, 2753-2764.

(20) Mendiola, J. A.; Herrero, M.; Cifuentes, A.; Ibanez, E. Use of compressed fluids for sample preparation: food applications. J. Chromatogr. A 2007, 1152, 234-246. 
(21) Valcarcel, M.; Tena, M. T. Applications of supercritical fluid extraction in food analysis. Fresenius' J. Anal. Chem. 1997, 358, 561573.

(22) Fornari, T.; Vicente, G.; Vazquez, E.; Garcia-Risco, M. R.; Reglero, G. Isolation of essential oil from different plants and herbs by supercritical fluid extraction. J. Chromatogr. A 2012, 1250, 34-48.

(23) Herrero, M.; Cifuentes, A.; Ibanez, E. Sub- and supercritical fluid extraction of functional ingredients from different natural sources: plants, food-by-products, algae and microalgae. Food Chem. 2006, 98, 136-148.

(24) Casas, L.; Mantell, C.; Rodriguez, M.; Gordillo, M. D.; Torres, A.; Macias, F. A.; Martinez de la Ossa, E. Effect of the pre-treatment of the samples on the natural substances extraction from Helianthus annuus L. using supercritical carbon dioxide. Talanta 2005, 67, 175181.

(25) Casas, L.; Mantell, C.; Rodriguez, M.; Torres, A.; Macias, F. A.; Martinez de la Ossa, E. J. Supercritical fluid extraction of bioactive compounds from sunflower leaves with carbon dioxide and water on a pilot plant scale. J. Supercrit. Fluids 2008, 45, 37-42.

(26) Casas, L.; Mantell, C.; Rodriguez, M.; Torres, A.; Macias, F. A.; Martinez de la Ossa, E. J. SFE kinetics of bioactive compounds from Helianthus annuus L. J. Sep. Sci. 2009, 32, 1445-1453.

(27) Casas, L.; Mantell, C.; Rodriguez, M.; Torres, A.; Macias, F. A.; Martinez de la Ossa, E. Extraction of natural compounds with biological activity from sunflower leaves using supercritical carbon dioxide. Chem. Eng. J. (Amsterdam, Neth.) 2009, 152, 301-306.

(28) El Marsni, Z.; Casas, L.; Mantell, C.; Rodriguez, M.; Torres, A.; Macias, F. A.; Martinez de la Ossa, E. J.; Molinillo, J. M. G.; Varela, R. M. Potential allelopathic of the fractions obtained from sunflower leaves using supercritical carbon dioxide. J. Supercrit. Fluids 2011, 60, 28-37.

(29) Macias, F. A.; Varela, R. M.; Torres, A.; Molinillo, J. M. G. In Potential of Cultivar Sunflowers (Helianthus annuus L.) as a Source of Natural Herbicide Templates; CRC: Boca Raton, FL, USA, 1999; pp 531-550.

(30) Rial, C.; Novaes, P.; Varela, R. M.; JM, G. M.; Macias, F. A. Phytotoxicity of cardoon (Cynara cardunculus) allelochemicals on standard target species and weeds. J. Agric. Food Chem. 2014, 62, 6699-6706.

(31) López, A. Estudios Alelopáticos de variedades Cultivadas de Girasol. SH-222 y Stella. Ph.D. dissertation, Universidad de Cádiz, Spain, 2003.

(32) Cutler, H. G.; Cutler, S. J.; Matesic, D. In Mode of Action of Phytotoxic Fungal Metabolites; CRC: Boca Raton, FL, USA, 2004; pp 253-270.

(33) Macias, F. A.; Torres, A.; Galindo, J. L. G.; Varela, R. M.; Alvarez, J. A.; Molinillo, J. M. G. Bioactive terpenoids from sunflower leaves cv. Peredovick. Phytochemistry 2002, 61, 687-692.

(34) Macias, F. A.; Castellano, D.; Molinillo, J. M. G. Search for a standard phytotoxic bioassay for allelochemicals. selection of standard target species. J. Agric. Food Chem. 2000, 48, 2512-2521.

(35) Macias, F. A.; Torres, A.; Molinillo, J. M. G.; Varela, R. M.; Castellano, D. Potential allelopathic sesquiterpene lactones from sunflower leaves. Phytochemistry 1996, 43, 1205-1215.

(36) Chiapusio, G.; Sanchez, A. M.; Reigosa, M. J.; Gonzalez, L.; Pellissier, F. Do germination indices adequately reflect allelochemical effects on the germination process? J. Chem. Ecol. 1997, 23, 24452453.

(37) Williams, R. D.; Hoagland, R. E. The effects of naturally occurring phenolic compounds on seed germination. Weed Sci. 1982, $30,206-212$.

(38) Macias, F. A.; Velasco, R. F.; Alvarez, J. A.; Castellano, D.; Galindo, J. C. G. Synthesis of melampolides and cis,cis-germacranolides as natural herbicide models. Tetrahedron 2004, 60, 8477-8488.

(39) Macias, F. A.; Galindo, J. C. G.; Molinillo, J. M. G.; Cutler, H. G. Allelopathy: Chemistry and Mode of Action of Allelochemicals; CRC: Boca Raton, FL, USA, 2004; p 372.

(40) Macias, F. A.; Galindo, J. C. G.; Molinillo, J. M. G.; Castellano, D. "Natural products as allelochemicals". 10. Dehydrozaluzanin C: a potent plant growth regulator with potential use as a natural herbicide template. Phytochemistry 2000, 54, 165-171.

(41) Spring, O.; Kupka, J.; Maier, B.; Hager, A. Biological activities of sesquiterpene lactones from Helianthus annuus: antimicrobial and cytotoxic properties; influence on DNA, RNA, and protein synthesis. Z. Naturforsch. C 1982, 37, 1087-1091.

(42) Kato, T.; Tsunakawa, M.; Sasaki, N.; Aizawa, H.; Fujita, K.; Kitahara, Y.; Takahashi, N. Growth and germination inhibitors in rice husks. Phytochemistry 1977, 16, 45-48.

(43) Picman, A. K.; Schneider, E. F. Inhibition of fungal growth by selected sesquiterpene lactones. Biochem. Syst. Ecol. 1993, 21, 307314.

(44) Macias, F. A.; Marin, D.; Oliveros-Bastidas, A.; Castellano, D.; Simonet, A. M.; Molinillo, J. M. G. Structure-activity relationships (SAR) studies of benzoxazinones, their degradation products and analogues. phytotoxicity on standard target species (STS). J. Agric. Food Chem. 2005, 53, 538-548.

(45) Roseland, C. R.; Grosz, T. J. Induced responses of common annual sunflower Helianthus annuus L. from geographically diverse populations and deterrence to feeding by sunflower beetle. J. Chem. Ecol. 1997, 23, 517-542.

(46) Inderjit; Dakshini, K. M. M. Hesperetin 7-rutinoside (hesperidin) and taxifolin 3-arabinoside as germination and growth inhibitors in soils associated with the weed, Pluchea lanceolata (DC) C.B. Clarke (Asteraceae). J. Chem. Ecol. 1991, 17, 1585-1591.

(47) Harborne, J. B.; Smith, D. M. Anthochlors and other flavonoids as honey guides in the Compositae. Biochem. Syst. Ecol. 1978, 6, 287291. 